\title{
POPULATION STRUCTURE AND DYNAMICS AND HABITAT CONDITIONS OF THE NATIVE CRAYFISH AUSTROPOTAMOBIUS PALLIPES IN A POND : A CASE STUDY IN BASQUE COUNTRY (NORTHERN IBERIAN PENINSULA).
}

\author{
A. RALLO and L. GARCÍA-ARBERAS.
}

Departamento de Zoología, Universidad del País Vasco, Apdo. 644, 48080-Bilbao, Spain.

\begin{abstract}
A natural and in appearance healthy population of the native crayfish Austropotamobius pallipes inhabiting a pond near Bilbao has been studied for three years, together with abiotic conditions of their habitat. The population occupies a littoral fringe (100 $\mathrm{m}$ length, $6 \mathrm{~m}$ width and approximately $1.5 \mathrm{~m}$ maximum depth), and has an estimated average density of $1.67 \mathrm{specimen} / \mathrm{m}^{2}$. Despite the very high conductivity of the water (all values are above $1,750 \mu \mathrm{S} / \mathrm{cm}$ ), total net production in the period 94-96 was $2,571.1 \pm 460.0 \mathrm{~g}\left(4.3 \pm 0.8 \mathrm{~g} / \mathrm{m}^{2}\right)$, with a productivity rate of $0.18 \pm 0.04$ measured as Production/Biomass $(P / B)$ index. We think that population equilibrium with the carrying capacity of the pond ecosystem is reached.
\end{abstract}

Key-words : crayfish, native species, population, pond, ecology, Spain.

STRUCTURE DE POPULATION, DYNAMIQUES ET CONDITIONS D'HABITAT DE L'ÉCREVISSE AUTOCHTONE AUSTROPOTAMOBIUS PALLIPES DANS UNE MARE : UN CAS D'ÉTUDE AU PAYS BASQUE (NORD DE LA PÉNINSULE IBÉRIQUE).

\section{RÉSUMÉ}

Une population naturelle apparemment saine d'écrevisses autochtones Austropotamobius pallipes peuplant une mare près de Bilbao a fait l'objet d'une étude sur trois ans, ainsi que s'intéressant aux conditions abiotiques de l'habitat. La population occupe une frange littorale (100 $\mathrm{m}$ de long, $6 \mathrm{~m}$ de large et environ 1,5 $\mathrm{m}$ maximum de profondeur), pour une densité évaluée à 1,67 individu $/ \mathrm{m}^{2}$. En dépit de la très haute conductivité de l'eau (toutes les valeurs sont au-dessus de $1750 \mu \mathrm{S} / \mathrm{cm}$ ), la production totale nette durant la période $94-96$ a été de $2571,1 \pm 460,0 \mathrm{~g}\left(4,3 \pm 0,8 \mathrm{~g} / \mathrm{m}^{2}\right)$, avec un taux de productivité de $0,18 \pm 0,04$ mesuré comme index Production/Biomasse (P/B). Nous pensons que l'équilibre de population que peut porter l'écosystème de la mare est atteint.

Mots-clés : écrevisse, espèces autochtones, population, mare, écologie, Espagne. 


\section{INTRODUCTION AND OBJECTIVES}

Freshwater ecosystems in Basque Country are almost all rivers. There are no lakes or natural ponds excepting a few very special cases related with diapiric structures. There are also artificial ponds, indirectly (by excavating to extract ores) or directly (reservoirs) man-made. For years, local people have been introducing crayfish from rivers into these ponds (and they continue to do so, but now not with native crayfish but with the alien species like red swamp crayfish). Now that the native crayfish is in a critical situation in rivers, an investigation into possible populations inhabiting ponds is being carried out.

A long-inhabiting and apparently healthy population of the native Austropotamobius pallipes dwells in an isolated pond near Bilbao. The population and its habitat have been studied for three years (1994 to 1996) with the following objectives:

1. to characterize habitat conditions and their changes with time,

2. to evaluate population numbers and conditions,

3. to work out the relationships between habitat and population conditions,

4. to evaluate the possibility of using this population in pilot programs for restocking native crayfish in rivers.

\section{POND DESCRIPTION AND METHODS}

The pond occupies a cavity in a diapiric area, where mineral was extracted for centuries. Its area is about $2,000 \mathrm{~m}^{2}$ large and the greatest depth detected is $3.2 \mathrm{~m}$, but it is not deeper than $1.5 \mathrm{~m}$ in the littoral fringe where crayfish inhabit (see results).

The study was performed on July of the years 1994, 1995 and 1996. Water conditions were measured at $20 \mathrm{~cm}$ below the surface (samples A) and near the bottom (samples B) at three points (samples 1, 2 and 3 ; so labels indicate year_level, Figure 1) in the zones inhabited by crayfish. Temperature, $\mathrm{pH}$, conductivity and chemicals dissolved in the water were recorded using standard apparatus and methods. Throughout the text data are given as average \pm standard deviation.

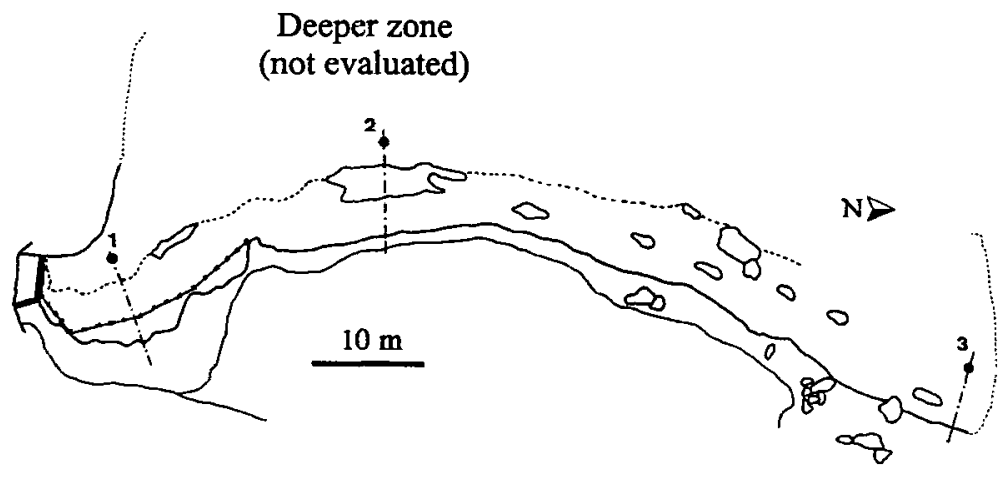

Figure 1

Diagram of the pond and location of crayfish population and sampling sites.

Figure 1

Diagramme de la mare et localisation de la population d'écrevisses et lieux d'échantillonage. 
Crayfish were captured using two-mouthed cylindrical baited traps (dimension : $48 \mathrm{~cm}$ length $\times 24 \mathrm{~cm}$ diameter ; entrance at the bottom of the cone $6 \mathrm{~cm}$ and mesh size $1 \mathrm{~cm}$ ). On the section where most of them are and at distances of 1 and $5 \mathrm{~m}$ from the edge of the pond, over thirty traps were regularly arranged. Each specimen was measured (length and weight) and its sex recorded. The body length of the crayfish was measured to the nearest $1 \mathrm{~mm}$ in two ways : total length (TL), from the tip of the rostrum to the end of the telson, and cephalotorax length (CL), from the tip of the rostrum to the end of the carapace. Crayfish were also weighted with a dynamometer to the nearest $1 \mathrm{~g}$ and then put back to the pond, excepting in recaptures when a few of them were taken away for laboratory studies. Population numbers are calculated by capture/recapture method (PETERSEN's method, with variance calculated as by NEWMAN and MARTIN, 1983).

Two related data matrices were used : abiotic samples (including both physical and chemical conditions) and population and associated values (individual numbers, sex, length and weight measures) samples. The results were analysed by statistical methods (descriptive statistics, multivariate analysis, etc.) using computer programs (StatGraphics Plus, NTSYS, ROHLF, 1992). Size classes were determined by BHATTACHARYA's method (BHATTACHARYA, 1967) ; productivity and production figures were obtained using Pop/Pro software (KWAK, 1992).

\section{RESULTS AND DISCUSSION}

\section{Presence and evaluation of the crayfish population}

Crayfish can be observed in the shoreline of the pond grazing and moving around the aquatic vegetation. Most of the population occupies a band some 6 meters wide and $100 \mathrm{~m}$ long ; actually, deepest zones seem not to be occupied excepting occasionally, as is the usual case in ponds and lakes (Plansee in Tyrol, FÜREDER and MACHINO, 1995 ; Irish reservoir, MATTHEWS and REYNOLDS, 1995). So, we studied an approximate area of $600 \mathrm{~m}^{2}$.

First we observed that due to the capture method small length animals are not trapped : the smallest exemplars collected were of $45 \mathrm{~mm}$ (males) and $50 \mathrm{~mm}$ (females), total length (TL). Thus all the following analysis and comments refer to craytish specimens of trappable size, longer than the above-cited measures.

The total number of different specimens captured (captured in both captures minus recaptured ones) was 454 in 1994, 550 in 1995 and 609 in 1996. The average rate of catches per trap for all the study was $9.8 \pm 1.8$ ind./trap. The captures of each sampling date and the most probable population numbers, calculated by capture/recapture method, are :

The most probable population numbers and their standard deviations remain relatively constant over the three sampling years, at around 1,000 exemplars, so that

$\begin{gathered}\text { Sampling } \\
\text { dates }\end{gathered}$ Total
captures recaptured of traps ind./trap \begin{tabular}{c} 
Number Average $\begin{array}{c}\text { Most } \\
\text { probable } \\
\text { number }\end{array}$ \\
\hline
\end{tabular}

\begin{tabular}{ccccccc}
\hline $29 / 06 / 94$ & 235 & 0 & 31 & 7.6 & & \\
$06 / 07 / 94$ & 247 & 58 & 31 & 8.0 & 1,001 & 429.5 \\
\hline $27 / 06 / 95$ & 304 & 0 & 33 & 9.2 & & \\
$04 / 07 / 95$ & 342 & 96 & 33 & 10.4 & 1,052 & 473.8 \\
\hline $09 / 07 / 96$ & 382 & 0 & 32 & 11.9 & & \\
$16 / 07 / 96$ & 369 & 142 & 32 & 11.5 & 982 & 478.0 \\
\hline
\end{tabular}


population seems not to have increased. The estimated population density is of $1.67 \mathrm{crayfish} / \mathrm{m}^{2}$. MATTHEWS and REYNOLDS (1995) found 1,000 crayfish of trappable size (in their case, above $20 \mathrm{~mm}$, carapace length) in a $200 \mathrm{~m}^{2}$ Irish reservoir.

Population was not mating in the sampling period (as fecundated females were captured since October). The sex proportions of the captured samples show a dominance of males, especially in 1995. The $\chi^{2}$ test precludes the $1: 1$ hypothesis, because the likelihood of this hypothesis being true is $0.008 \%$ in $1994,0.00 \%$ in 95 and $2.6 \%$ in 96 (Figure 2). In the particular case of 1995 the data fitted very well into a males/females proportion of $2: 1\left(\chi^{2}=0.028 ; P=86.74 \%\right)$. It is difficult to know if this is the true situation of the population (females and males are both equally active and trappable during sampling dates), or an effect of the capture method making more likely males to be captured than females. The previously cited authors also found a dominance of males in some cases, in Ireland. This situation is the opposite to the case of populations of native crayfish in rivers, captured by hand in the same period (GARCIA-ARBERAS and RALLO, 1999).

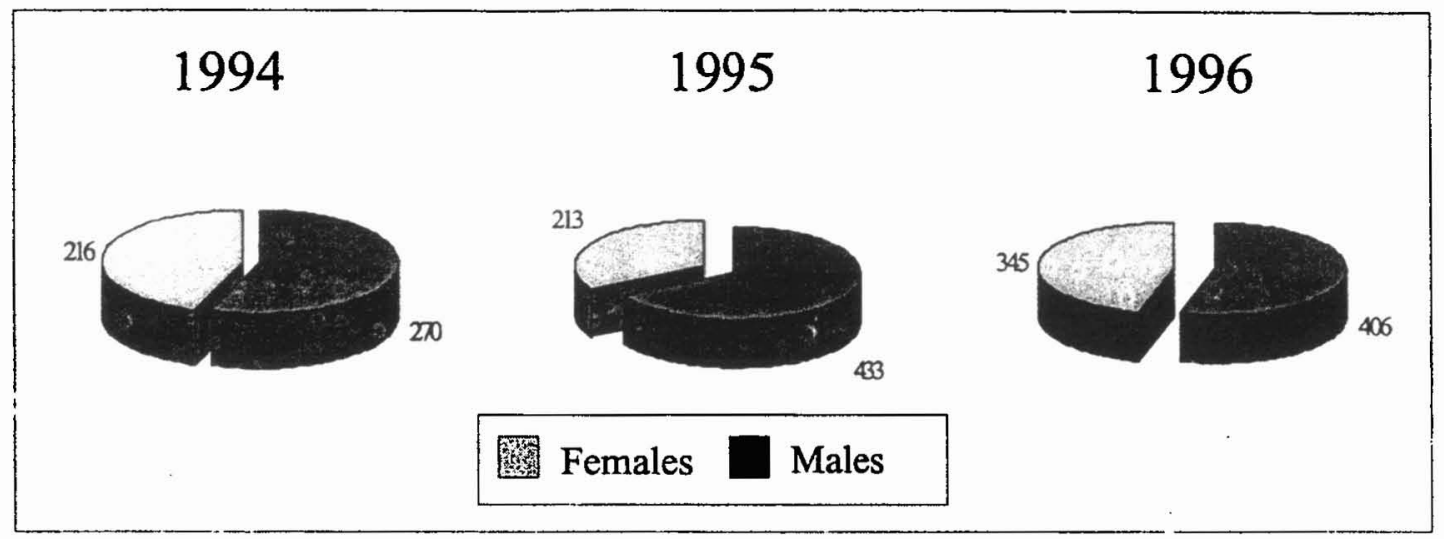

Figure 2

Sex ratios as percentages. Three years are represented.

\section{Figure 2}

Sex ratio en pourcentages. Trois années sont représentées.

Size of crayfishes has been recorded. Total length and weight averages are greater in males than in females (analysis made using data from the three years : length, $\chi^{2}=175.7 ; P=0 \%$, weight, $\chi^{2}=1,301.3 ; P=0 \%$ ). (Figure 3 ).

The lengths obtained by the two traditional measuring procedures (total rostrum-telson length, TL, and cephalotorax or carapace length, $C L$ ) are, obviously, very closely linked : $T L=12.19+1.75 \times C L\left(r^{2}=92.57\right.$; number of cases $\left.=1,583\right)$. Tested by covariance analysis in order to extract the $\mathrm{CL}$ weight, significant differences in $\mathrm{TL}$ according to year and sex are detected, so the following regression equations were obtained : 

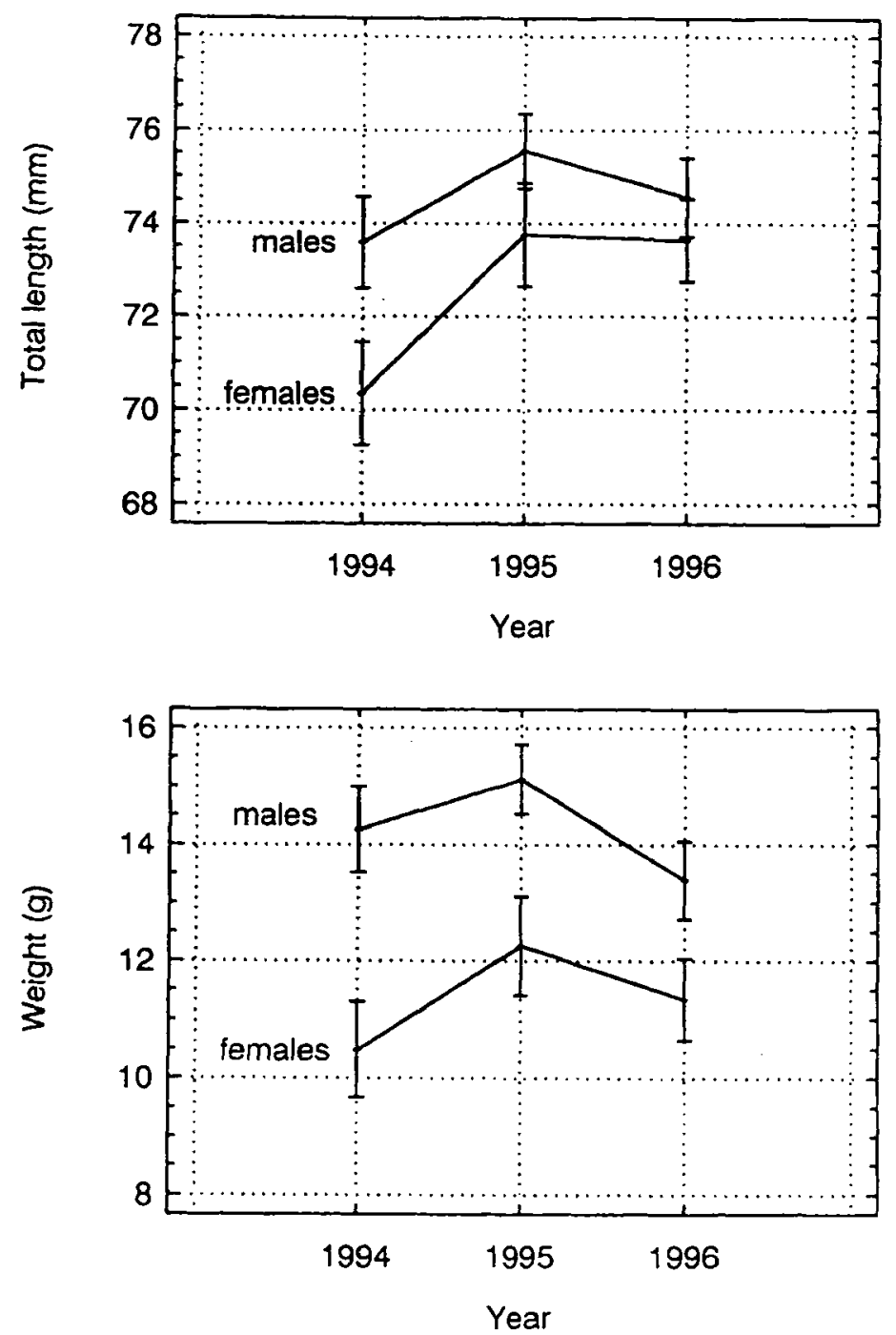

Figure 3

Length and weight differences between males and females. Males are longer and heavier than females ( $95 \%$ confidence level).

\section{Figure 3}

Différences de longueur et de poids entre mâles et femelles. Les mâles sont plus longs et plus lourds que les femelles (95\% de marge de confiance).

In these equations the intercept is not significantly different between males and females ( $\mathrm{t}$-test $=1.8379$ at $95 \%$ ). Oppositely, slopes are significantly higher in females (t-test $=-6.1872$ at $95 \%$ ), possibly showing that when growing, the abdomen of females becomes proportionally longer than that of males. These results are different from those found by GRANDJEAN et al. (1997a) in a french population.

Also weight (W, g) is also clearly related to body length (TL, $\mathrm{mm}$ ), according to the multiplicative model $W=0.0002 \times T^{3.120}\left\langle r^{2}=92.57 ; n=1,582\right.$ cases ; significative at $95 \%$ ). Significant differences in W adjusting for the differences in TL and according to year and sex are detected (ANCOVA analysis), so we can separate cases by these two factors. The most fitted regression equations are : 
Year Males

$1994 W=0.023 \times T^{3.181}$

$1995 W=0.017 \times T L^{3.322}$

$1996 \mathrm{~W}=0.019 \times \mathrm{TL}^{3.273}$

\begin{tabular}{ccccc}
\multicolumn{9}{c}{ Females } \\
$r^{2}$ & N.cases $^{*}$ & & & \\
92.02 & 218 & $W=0.050 \times \mathrm{TL}^{2.721}$ & 89.11 & 163 \\
91.36 & 315 & $\mathrm{~W}=0.046 \times \mathrm{TL}^{2.756}$ & 87.08 & 164 \\
91.81 & 285 & $\mathrm{~W}=0.034 \times \mathrm{TL}^{2.895}$ & 91.20 & 253
\end{tabular}

*damaged crayfish are not included in the analysis

These models also show different males and females intercept and slope values $(t=-4.622$ and 6.952 , respectively), with the following averages :

Intercept : males $=0.197 \pm 0.003 ;$ females $=0.043 \pm 0.008$

Slope : $\quad$ males $=3.259 \pm 0.072 ;$ females $=2.790 \pm 0.092$

The data in Table I result from the analysis of the size frequencies distribution (measured as TL ; Figures 4 and 5), determined by BHATTACHARYA's method (BHATTACHARYA, 1967). Although the decomposition of these frequency distributions into gaussian curves is not always significant, we can propose a distinction in two classes, III and IV, whose respective average size increases in 1996, males belonging to class IV excluded. But we were told that, as a management action, gamekeepers have taken away several of the largest males (about fifty) in the 1995 season. So this size increment is interpreted as an ageing phenomenon.

\section{Table I}

Proposed size classes, as calculated by length frequency analysis. Number of individuals belonging to each one, percentage and separation index are indicated.

\section{Tableau I}

Classes de taille proposées, calculées à partir d'une analyse de fréquence de longueur. Le nombre d'individus appartenant à chaque classe, le pourcentage et l'index de séparation sont indiqués.

\begin{tabular}{|c|c|c|c|c|}
\hline 1994 & \multicolumn{4}{|c|}{ males } \\
\hline classes & $x \pm$ s.d. & $\mathrm{N}$ & $\%$ & S.I. \\
\hline III & $6.6 \pm 0.6$ & 85 & 36.8 & - \\
\hline IV & $8.0 \pm 0.5$ & 146 & 63.2 & 2.46 \\
\hline 1995 & \multicolumn{4}{|c|}{ males } \\
\hline classes & $x \pm$ s.d. & $N$ & $\%$ & S.I. \\
\hline III & $6.4 \pm 0.7$ & 58 & 16.4 & - \\
\hline IV & $7.8 \pm 0.6$ & 295 & 86.6 & 2.22 \\
\hline 1996 & \multicolumn{4}{|c|}{ males } \\
\hline classes & $x \pm$ s.d. & $N$ & $\%$ & S.I. \\
\hline III & $6.9 \pm 0.5$ & 167 & 52.7 & - \\
\hline IV & $7.9 \pm 0.5$ & 150 & 47.3 & 1.86 \\
\hline
\end{tabular}

\begin{tabular}{rccc}
\multicolumn{4}{c}{ females } \\
\hline x \pm s.d. & $N$ & $\%$ & S.I. \\
$6.1 \pm 0.3$ & 56 & 30.1 & - \\
$7.6 \pm 0.6$ & 130 & 69.9 & 3.22
\end{tabular}

\begin{tabular}{rccc}
\multicolumn{4}{c}{ females } \\
\hline $\mathrm{x} \pm$ s.d. & $\mathrm{N}$ & $\%$ & $\mathrm{~S} . \mathrm{I}$ \\
$6.1 \pm 0.4$ & 31 & 16.5 & - \\
$7.5 \pm 0.7$ & 157 & 83.5 & 2.54
\end{tabular}

* S.I. : Separation Index between groups ; differences are significative when the index is greater than 2 

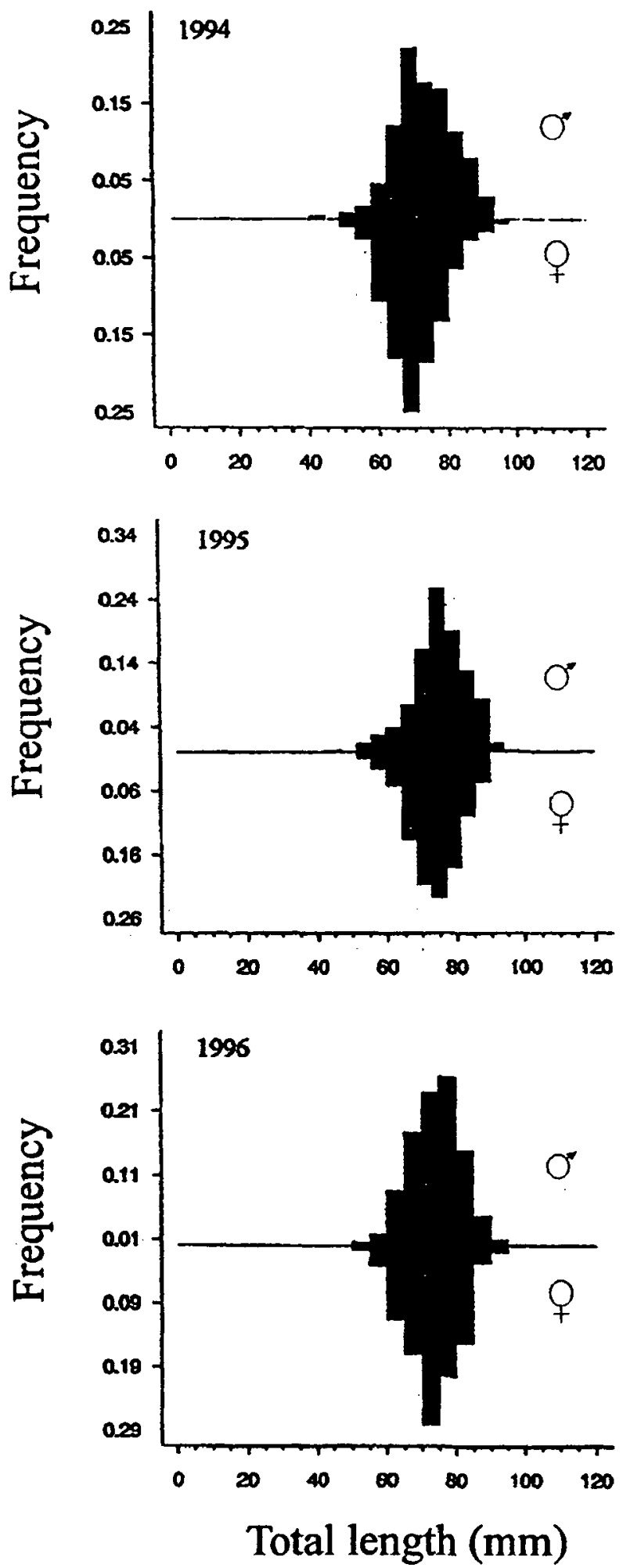

Figure 4

Frequency analysis of body lengths in three years. Above the axis : males ; below : females.

Figure 4

Analyse de fréquence des longueurs du corps au cours des trois années. Au-dessus de l'axe : les mâles; en-dessous : les femelles. 


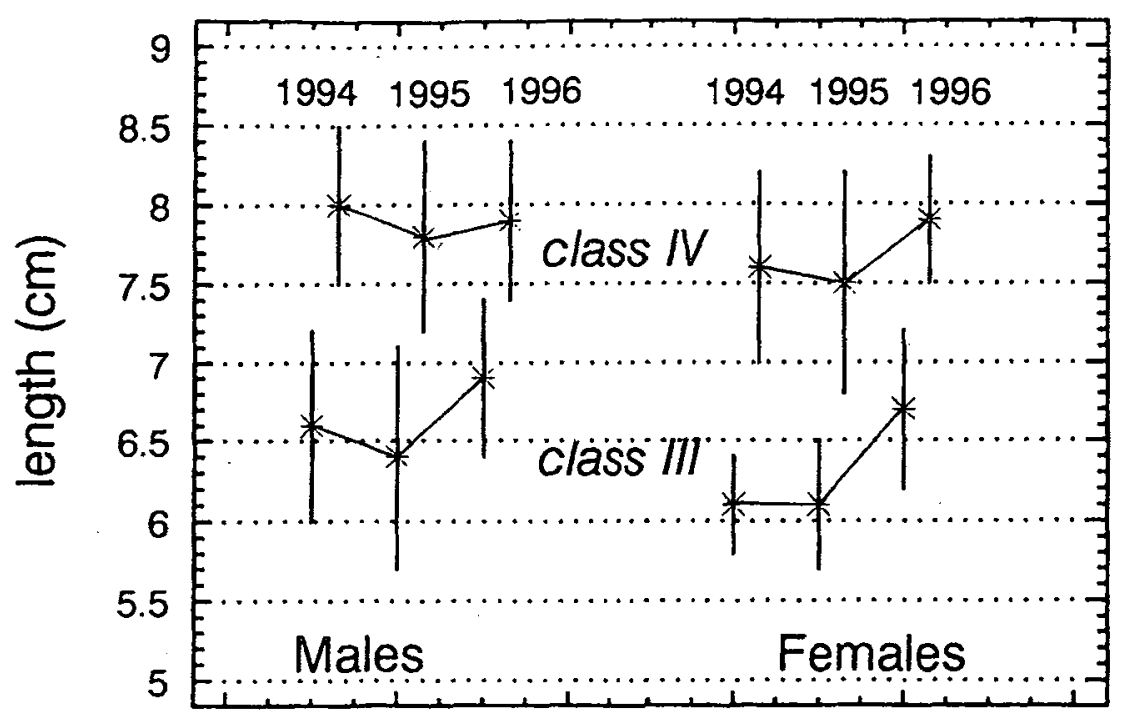

Figure 5

Most probable total-length averages of crayfish for each size (or age) class, defined by sex and year. Standard deviation intervals are represented.

\section{Figure 5}

Moyenne la plus problable de la taille totale pour les écrevisses de chaque groupe de taille (ou d'âge), selon le sexe et l'année. Les intervalles d'écart standard sont représentés.

The total net production from 1994 to 1996 was $2,571.1 \pm 460.0 \mathrm{~g}\left(4.3 \pm 0.8 \mathrm{~g} / \mathrm{m}^{2}\right)$, with a productivity rate of $0.18 \pm 0.04$ measured as a $P / B$ index. Net production is not very high, also demonstrating that population equilibrium with the carrying capacity of the pond ecosystem is reached.

\section{Conditions of the habitat}

The waters of the pond, associated with a gypsum diapiric system, have a high degree of conductivity : recorded values are all above $1,750 \mu \mathrm{S} / \mathrm{cm}$, with an average of $2,217.2 \pm 159.6 \mu \mathrm{S} / \mathrm{cm}$. Correspondingly, concentrations of sulphates, calcium and magnesium are very high. The values of these and other main chemical ionic species concentrations and physical conditions are :

$\begin{array}{lrll}\mathrm{T} & 15.76 & \pm 1.42 & { }^{\circ} \mathrm{C} \\ \mathrm{pH} & 7.96 & \pm 0.14 & \\ \text { QDO } & 8.31 & \pm 5.00 & \\ \text { hardness } & 144.84 & \pm 28.61 & \mathrm{o} \\ \text { sulphate } & 1,364.50 & \pm 150.37 \mathrm{mg} / \mathrm{l} \\ \text { chloride } & 2.79 & \pm 2.7 & \mathrm{mg} / \mathrm{l} \\ \text { bicarbonate } & 44.99 & \pm 62.41 & \mathrm{mg} / \mathrm{l} \\ \text { calcium } & 408.83 & \pm 116.58 \mathrm{mg} / \mathrm{l} \\ \text { magnesium } & 103.94 & \pm 25.58 \mathrm{mg} / \mathrm{l} \\ \text { potassium } & 0.79 & \pm 0.25 & \mathrm{mg} / \mathrm{l} \\ \text { sodium } & 4.80 & \pm 3.45 & \mathrm{mg} / \mathrm{l} \\ \text { nitrates } & 0.61 & \pm 0.61 & \mathrm{mg} / \mathrm{l} \\ \text { nitrites } & 0.011 & \pm 0.004 & \mathrm{mg} / \mathrm{l} \\ \text { ammonium } & 0.16 & \pm 0.15 & \mathrm{mg} / \mathrm{l}\end{array}$


The high conductivity is particularly interesting : natural gypsum content in the water is very high, but the crayfish population seems nevertheless to be healthy. Also the concentration values variability is great, especially in the cases of $\mathrm{Cl}^{-}$and $\mathrm{CO}_{4} \mathrm{H}^{-}$, what proves that the water chemical composition is both spatially and temporally-very heterogeneous : underwater springs bring either bicarbonated or chlorinated flows from different places and, besides, part of the pond is faintly illuminated because it occupies a cave, whilst the other part is directly reached by sun.

\section{Table II}

Principal component analysis : significance of axes and weight of the variables.

\section{Tableau II}

Analyse des composantes principales : signification des axes et variables de" poids.

\begin{tabular}{cccccc}
\hline $\begin{array}{c}\text { Principal } \\
\text { component }\end{array}$ & Eigenvalue & Percent & $\begin{array}{c}\text { Cumulative } \\
\text { percent }\end{array}$ & Expected & $\begin{array}{c}\text { Axis } \\
\text { significance }\end{array}$ \\
\hline $\mathbf{1}$ & 9.698980 & 48.4949 & 48.4949 & 17.9887 & yes \\
$\mathbf{2}$ & 3.365365 & 16.8268 & 65.3217 & 12.9887 & yes \\
$\mathbf{3}$ & 2.567141 & 12.8357 & 78.1574 & 10.4887 & yes \\
$\mathbf{4}$ & 1.303061 & 6.5153 & 84.6727 & 8.8220 & not
\end{tabular}

\begin{tabular}{|c|c|c|c|}
\hline $\begin{array}{c}\text { Principal } \\
\text { component } \\
\text { axis : }\end{array}$ & 1 & 2 & 3 \\
\hline \multicolumn{4}{|l|}{ Variables } \\
\hline Depth & -0.088 & -0.024 & 0.630 \\
\hline $\mathrm{T}$ & 0.763 & -0.063 & -0.433 \\
\hline $\mathrm{pH}$ & -0.423 & 0.043 & -0.750 \\
\hline $\mathrm{O}_{2}$ & -0.170 & -0.402 & 0.660 \\
\hline QDO & 0.415 & -0.058 & -0.518 \\
\hline Conductivity & 0.246 & 0.927 & -0.019 \\
\hline Hardness & 0.955 & -0.154 & 0.161 \\
\hline $\mathrm{Cl}^{-}$ & -0.957 & 0.177 & -0.166 \\
\hline $\mathrm{SO}_{4}^{2-}$ & 0.698 & 0.449 & 0.103 \\
\hline $\mathrm{NO}_{3}^{-}$ & -0.690 & 0.482 & 0.226 \\
\hline $\mathrm{NO}_{2}^{-}$ & -0.319 & 0.562 & 0.110 \\
\hline Phosphates & 0.926 & -0.017 & -0.081 \\
\hline Silicates & 0.956 & 0.165 & 0.182 \\
\hline $\mathrm{Ca}^{2+}$ & 0.952 & 0.171 & 0.190 \\
\hline Magnesium & -0.046 & -0.959 & -0.035 \\
\hline $\mathrm{Na}^{+}$ & -0.961 & 0.218 & -0.118 \\
\hline $\mathrm{K}^{+}$ & -0.970 & 0.168 & -0.128 \\
\hline Bicarbonates & -0.380 & 0.086 & 0.691 \\
\hline $\mathrm{NH}_{4}^{+}$ & -0.567 & -0.686 & 0.001 \\
\hline Solids & 0.875 & -0.029 & -0.056 \\
\hline
\end{tabular}


The variability found in these habitat descriptors is summarised in a principal component analysis (Table II). It is associated to a first axis, defined by hardness and calcium, phosphate and silicates concentrations, which explains $48.5 \%$ of the total variance. A second significant axis (16.3\%) is defined by conductivity and magnesium concentration. Ordered by these two axes samples are grouped by the year of study (Figure 6). There is a third significant axis (12.84\%) which discriminates between surface (A) and bottom (B) samples. It is related to $\mathrm{pH}$ (negatively) and bicarbonate concentration (positively), so that photosynthetic activity must be taken into account. Nowadays a study is being carried on in order to delimit zones in the pond based on the water conditions.

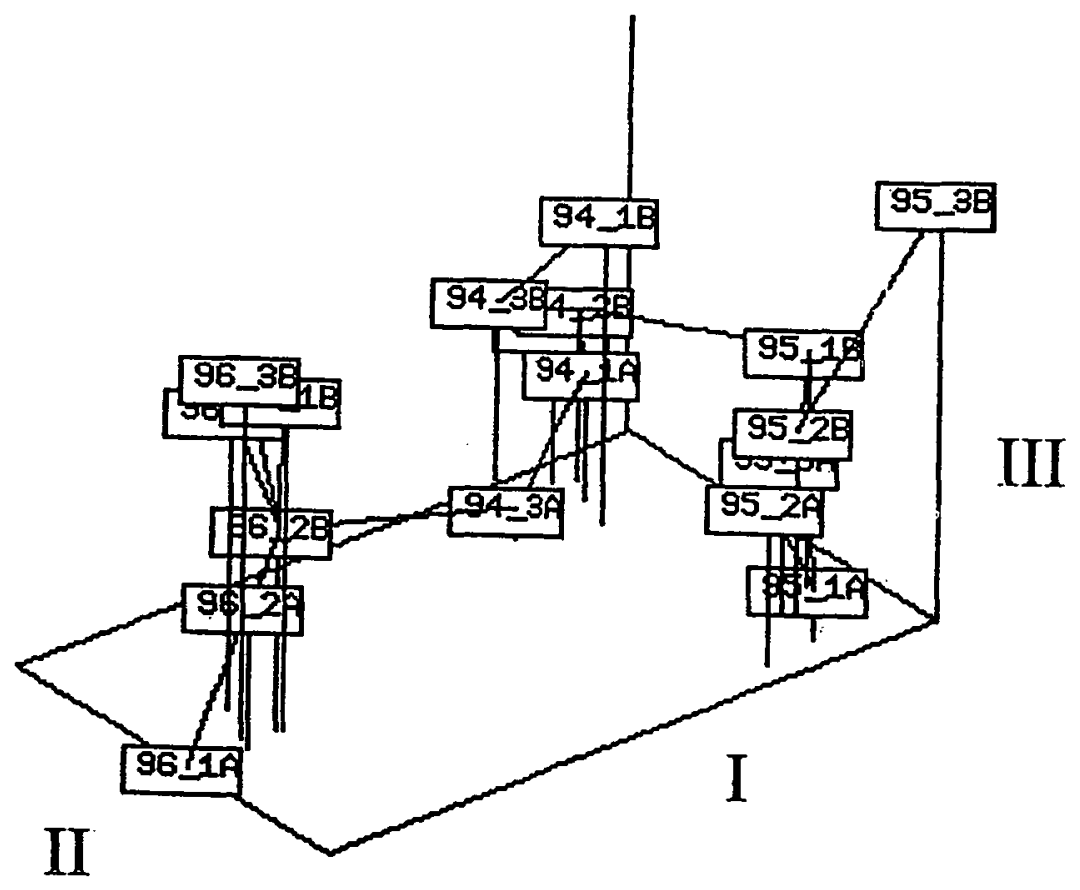

Figure 6

Grouping representation of abiotic water conditions in a three-dimensional space defined by principal components used as axes.

\section{Figure 6}

Représentation de groupe des conditions d'eau abiotiques dans un espace tridimensionnel défini par les principales composantes employées comme axes.

\section{Management recommendations}

Management measures in order to conserve the native crayfish population in this pond and to use it for restocking selected places must include the protection and improvement of the habitat, with control of fish, and the commencement of a genetic study to palliate the phenomenon of endemism. Although it is discussed (MATTHEWS and REYNOLDS, 1995), our hypothesis (as MOMOT and GOWING, 1977 ; MOMOT, 1991) is that the population rejuvenation would be afforded by extraction of individuals belonging to the biggest size groups. Furthermore, a study of sexual maturity is planned in order to delimit the size of the adult stage in both sexes, as GRANDJEAN et al. (1997b) recommend for restocking purposes. 


\section{ACKNOWLEDGEMENTS}

This study has been supported by the Departamento de Agricultura (Sección Pesca), Exma. Diputación de Bizkaia. We are specially indebted to E. ALVAREZ, Chief of the Service, and to the river guard of Bizkaia. We wish also to acknowledge the observations of the referees.

\section{REFERENCES}

BHATTACHARYA C.G., 1967. A simple method of resolution of a distribution into gaussian components. Biometrics, 23, 115-135.

FÜREDER L., MACHINO Y., 1995. Record of the white-clawed crayfish Austropotamobius pallipes (Lereboullet 1858) from Plansee (Tyrol, Austria). Ver. Nat.-med. Verein Innsbruck, 82, 241-246.

GRANDJEAN F., ROMAIN D., AVILA-ZARZA C., BRAMARD M., SOUTY-GROSSET C., MOCQUARD J.P., 1997a. Morphometric, sexual dimorphism and size at maturity of the white-clawed crayfish Austropotamobius pallipes pallipes (Lereboullet) from a wild french population at Deux-Sèvres (Decapoda, Astacidea). Crustaceana, 70, 1, 31-44.

GRANDJEAN F., ROMAIN D., SOUTY-GROSSET C., MOCQUARD J.P., 1997b. Size at the sexual maturity and morphometric variability in three populations of Austropotamobius pallipes (Lereboullet 1858) according to a restocking strategy. Crustaceana, 70, 4, 454-468.

GARCIA-ARBERAS L., RALLO A., 2000. Survival of natural populations of Austropotamobius pallipes in rivers in Bizkaia, Basque country (North of Iberian Peninsula). Bull. Fr. Pêche Piscic, 356, 13-26.

KWAK T.J., 1992. Modular microcomputer software to estimate fish population parameters, production rates and associated variance. Ecol. Freshwater Fish, 1(1), 73-75.

MATTHEWS M.A., REYNOLDS J.D., 1995. A population study of the white-clawed crayfish Austropotamobius pallipes (Lereboullet) in an Irish reservoir. Biol. and Environm., Proceed. Irish Royal Acad., 958 (2), 99-109.

MOMOT W.T., 1991. Potential for exploitation of freshwater crayfish in cool water systems : management guidelines and issues. Fisheries, 16 (5), 14-21.

MOMOT W.T., GOWING H., 1977. Response of the crayfish Orconectes virilis to exploitation. J. Fisheries Res. Board of Canada, 34, 1212-1219.

NEWMAN R.M., MARTIN F.B., 1983. Estimation of fish production rates and associated variances. Can. J. Fish. Aquat. Sci., 40, 1729-1736.

ROHLF F.J., 1992. NTSYS-pc. Numerical Taxonomy and Multivariate Analysis System. Exeter Software, N.Y., 215 p. 